\title{
Glaciation, erosion and the evolution of the Transantarctic Mountains, Antarctica
}

\author{
ANDREW KERR \\ Department of Geography, University of Edinburgh, Edinburgh EH8 9XP, Scotland \\ Alan Gilchrist \\ Coastal Mountain Consultants, 3504 Gordon Drive, Terrace, BC V8G 5P5, Canada
}

\begin{abstract}
Modelling studies of the tectonic evolution of the Transantarctic Mountains in Antarctica have drawn differing conclusions as to the primary mechanisms involved. None has considered the role of the East Antarctic ice sheet in detail. We use a denudation-flexural model to examine the isostatic response of the continental margin to glacial erosion to determine whether glacial processes have played a role in forcing mountain uplift.

The conclusion is that, although there are insufficient data formally to delimit the role of glacial erosion, available geophysical and geomorphological data are not inconsistent with the results of the differential denudation model, providing certain conditions are met. These results indicate that the current topography of the Transantarctic Mountains can be simulated, in part, from the isostatic response of the lithosphere to glacial erosion. The short wavelength and high amplitude of the Transantarctic Mountains do not require a low flexural rigidity in the unrifted lithosphere, provided there is a fast escarpment retreat from the rift hinge, high escarpment denudation rates and a large differential in denudation between the coastal zone and the interior.
\end{abstract}

\section{INTRODUCTION}

Debate coupling recent uplift of the Transantarctic Mountains with late Cenozoic instability of the East Antarctic ice sheet (Behrendt and Cooper, 1991) has focused attention on mechanisms which generate the uplifted flanks of rifted continental margins. Modelling studies of the Transantarctic Mountains (Drewry, 1983; Stern and ten Brink, 1989; ten Brink and Stern, 1992; Bott and Stern,1992; Beek and others, 1994) have drawn different conclusions as to the principal factors concerned, primarily because of their conflicting interpretations of the available geophysical and geomorphic data. Mechanisms proposed for uplift include thermal buoyancy due to lithospheric stretching (ten Brink and others, 1993), flexural uplift as a result of lithospheric necking (Beek and others, 1994) and the Vening Meinesz mechanism (Stern and ten Brink, 1989). Although all consider erosion to be important, none has considered the function of the ice sheet in detail. It remains unclear as to the extent to which the East Antarctic ice sheet has influenced the mechanisms driving the rifted continental margin uplift over geological time-scales.

The two aspects of glaciation which can influence regional tectonics are the ice load on the lithosphere and patterns of glacial erosion. Their influence is coupled to the time-scales over which they operate and, in the latter case, the effectiveness with which denudation occurs.
Glacial isostatic loading is more transitory, while modifying regional geomorphological processes can lead to permanent change, though they may of course be linked since the warping of the lithosphere by the ice sheet affects patterns of denudation over geological time-scales.

Here, we will examine one aspect of the problem, which concerns the isostatic response of the continental margin to glacial erosion, to determine whether glacial processes have played a role in forcing mountain uplift. The history of glaciation in East Antarctica is, however, a matter of debate. Offshore seismic data suggest that glaciation was occurring in the Transantarctic Mountains at least as far back as the Oligocene (Anderson and Bartek, 1992). Subsequently, the classical view holds that the ice sheet has been stable and in a form similar to that of today for over $12 \mathrm{Ma}$, since the development of a polar climate sometime after the opening of Drake Passage between South America and Antarctica during the Miocene (Sugden and others, 1993). The second, and currently more popular, view holds that the ice sheet has fluctuated dramatically throughout its existence until the end of the Pliocene $(\sim 3 \mathrm{Ma})$, since when a full polar climate has existed (Wilson, 1995).

Regardless of the outcome of this debate, the implication is that glacial processes have been operating in the Transantarctic Mountains for much of the Cenozoic, since rifting, uplift and denudation began 55-60 Ma (Fitzgerald, 1992). However, quantifying 
glacial erosion over millions of years and on regional scales is not possible using current process models of ice sheets. In addition, although it is possible to assert qualitatively that certain climatic conditions are more conducive to higher rates of glacial erosion, the data are insufficiently constrained to provide a detailed history of climatic fluctuations throughout the Cenozoic. Therefore, in an attempt to explore the geomorphological consequence of glaciation we apply the denudationalflexural model of Gilchrist and Summerfield (1990). This was developed to assess large-scale landscape evolution following supercontinent break-up and links denudation and isostasy across high-elevation, passive continental margins. These are characterized by dissected coastal zones with significant relief rising to an escarpment inland separating the coastal zone from the hinterland (Gilchrist and Summerfield, 1994). Such margins are similar to the current morphology and tectonic setting of the Transantarctic Mountains (Tessensohn and Worner, 1991).

\section{THE MODEL}

The model is taken from Gilchrist and Summerfield (1990) and consists of two parts: a dual-terrain model where differential rates of denudation across the continental margin are represented as regions of high and low relief separated by a moving boundary (Fig. 1) and a flexural model, which calculates the isostatic response to denudational unloading assuming a thin elastic plate of constant thickness overlying an inviscid fluid according to the equation

$$
\frac{\partial^{2}}{\partial x^{2}}\left(D \frac{\partial^{2} w}{\partial x^{2}}\right)+\left(\rho_{\mathrm{m}}-\rho_{\mathrm{i}}\right) g w=l(x)
$$

where $w$ is the vertical flexure, $D$ is the flexural rigidity, $\rho_{\mathrm{m}}$ is the mantle density, $\rho_{\mathrm{i}}$ is the density of the flexure infill (air), $g$ is the acceleration due to gravity, $l(x)$ is the denudational load as a function of $x$ and $x$ is the distance from the continental margin. (Nadai, 1963). The flexural

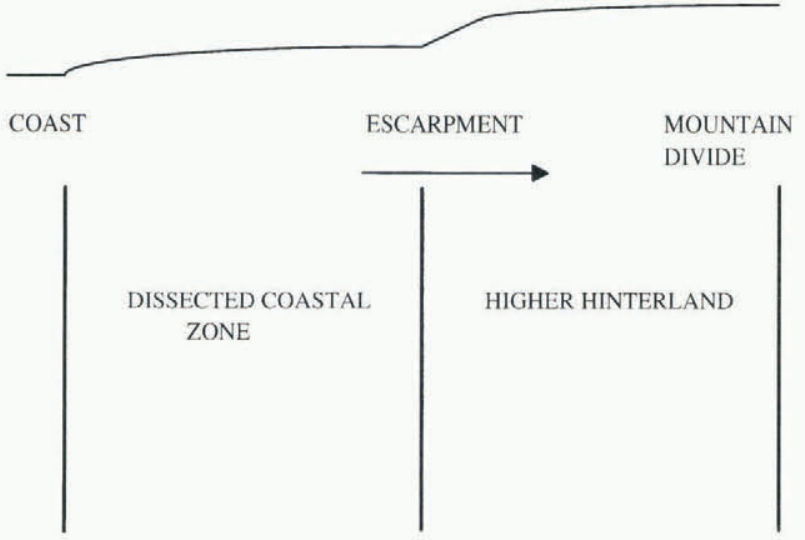

Fig. 1. A schematic diagram outlining the geometry of the model. Parameters are required for the rate of escarpment retreat and the denudation in the coastal zone, the hinterland and on the escarpment. rigidity is given by

$$
D=\frac{E T_{\mathrm{e}}^{3}}{12\left(1-v^{2}\right)}
$$

where $E$ is Young's modulus, $T_{\mathrm{e}}$ is the effective elastic thickness of the lithosphere and $v$ is Poisson's ratio. Vertical flexure is calculated in the wave-number domain from

$$
W(k)=R(k) L(k)
$$

where $R(k)$ is the isostatic response function, so

$$
R(k)=\frac{1}{\left(\rho_{\mathrm{m}}-\rho_{\mathrm{i}}\right) g+D k^{4}},
$$

and $W(k)$ and $L(k)$ are the Fourier transforms of $w(x)$ and $l(x)$, and $k$ is the wave number given by $k=2 \pi / \lambda$ where $\lambda$ is the wavelength. This acts as a low-pass filter to an applied load, so the spatial resolution of the denudational model is not critical in determining the isostatic response to denudation provided that deviations are relatively minor. The model parameters, which determine the flexural response to unloading, are the effective elastic thickness of the lithosphere in both the rifted and unrifted regions (Gilchrist and Summerfield, 1990).

The denudational model consists of four parameters which quantify the rate at which the escarpment retreats from the coast, and the rates of denudation in the coastal zone, in the interior and on the escarpment. It utilizes empirical estimates of long-term denudation which can be constrained independently using apatite fission-track data. The modelling should, therefore, be seen in the context of a parameter study to examine the role of glacial erosion on the dynamics of a passive margin; it does not seek to simulate all the relevant processes involved with tectonic uplift.

In addition, the model calculates the effect of loading sediments offshore on the margin morphology, using borehole data to constrain seismic interpretations of sediment age.

\section{DATA GONSTRAINTS}

Constraining the mechanisms which caused uplift of the Transantarctic Mountains depends critically on the use of the appropriate data. The inputs required for the model comprise denudation rates and flexural rigidities of the lithosphere. These latter parameters determine the amplitude and wavelength of uplift for a given load. Published values vary widely; modelling studies of the Transantarctic Mountains have used values of equivalent elastic thickness of $110 \mathrm{~km}$ dropping to $5 \mathrm{~km}$ at the continental margin (Stern and ten Brink, 1989; ten Brink and Stern, 1992), $100 \mathrm{~km}$ to $12.5 \mathrm{~km}$ (Bott and Stern, 1992 ), and $>40-50 \mathrm{~km}$ dropping to $20 \mathrm{~km}$ at the margin (Beek and others, 1994). The latter authors noted that the higher values were obtained because the topographic deflection was modelled solely as a line load acting at the margin. Instead, they used values based on coherence studies of topography and Bouguer gravity anomalies in analogous regions. In the first instance, we will use these 
latter figures.

The remaining inputs are rates of denudation across the continental escarpment which are quantified by four model parameters. Unfortunately, quantitative measures of the effectiveness of glacial denudation produce widely varying rates. Instead, more indirect methods are used. These are exemplified by Bell and Laine (1985), who used offshore seismic reflection data to argue that an equivalent of $120 \mathrm{~m}$ of rock had been eroded from the Laurentide region during the Quaternary; Hall and Sugden (1987), who provided evidence of the selectivity of glacial denudation from glacial and pre-glacial land forms; and Wellman and Tingey (1981), who calculated a rate of $50 \mathrm{~m} \mathrm{Ma}^{1}$ for Antarctica from isostatic considerations. Clearly, all these indirect methods are limited by the constraints of extrapolating data over wide spatial scales.

As an upper estimate, we take the highest value, that of $50 \mathrm{~m} \mathrm{Ma}^{-1}$, for the coastal-zone denudation rate and a proportionately smaller value for the interior, encapsulating the myriad of processes leading to lower denudation rates in colder, less maritime regions. The lack of denudation data for areas other than the coastal zones and escarpments necessarily limits modelling to numerical exploration of the parameter space.

The simplest parameter to calculate is the escarpment retreat rate, since the maximum elevation of the Transantarctic Mountains escarpment in the Dry Valley region lies about $80 \mathrm{~km}$ from the coast, which is taken to be the rift hinge. Since rifting and denudation began $\sim 55-60 \mathrm{Ma}$, this provides a mean rate of escarpment retreat, though in practice retreat rates would vary markedly with climatic and glacial conditions.

These parameters, coupled to a high denudation rate on the escarpment, determine the volume of sediment eroded through time. This combined figure is tightly constrained by apatite fission-track data which provide an estimate of total denudation, assuming a reasonable geothermal model (Gleadow and Fitzgerald, 1987; Fitzgerald, 1992). In the Dry Valleys sector of the Transantarctic Mountains, denudation has removed a wedge of material of more than $5 \mathrm{~km}$ near the coast, reducing to $1 \mathrm{~km}$ and $75 \mathrm{~km}$ inland.

The remaining input is the initial topography. Gleadow and Fitzgerald (1987) suggested a plateau elevation of $500 \mathrm{~m}$, a value which has attained axiomatic status though it is poorly constrained, while Sugden and others (1995) suggested an equally poorly constrained $1200 \mathrm{~m}$. We explore the implications of both these initial elevations, plus a third which has a block at the continental margin of $1200 \mathrm{~m}$ elevation with the hinterland at an elevation of $500 \mathrm{~m}$, since there was tectonic uplift and denudation in the early Cretaceous (Fitzgerald, 1992 .

Comparison with the gross morphology of the present continental margin is complicated by the existence of the ice sheet. Assumptions concerning the flexural rigidity of the lithosphere will implicitly determine the effect of the ice sheet. Using a broken, variable rigidity model, Stern and ten Brink (1989) calculated the ice load alone depresses the lithosphere by over $800 \mathrm{~m}$ about $500 \mathrm{~km}$ inland from the Transantarctic Mountains but has only a small effect at the coast. This differs from the analysis by
Table 1. The input parameters to the model

Effective elastic thickness - unrifted lithosphere

Effective elastic thickness - rifted lithosphere

Interior denudation rate

Coastal zone denudation rate

Escarpment retreat rate

Escarpment denudation rate

Model run time

Initial elevation of topography

$40 \mathrm{~km}$

$20 \mathrm{~km}$

$5 \mathrm{~m} \mathrm{Ma}^{-1}$

$50 \mathrm{~m} \mathrm{Ma}$

$1450 \mathrm{~m} \mathrm{Ma}^{1}$

$3500 \mathrm{~m} \mathrm{Ma}^{1}$

$60 \mathrm{Ma}$

$1200 \mathrm{~m}$

Drewry (1983), who suggested subsidence in the Transantarctic Mountains. The difference reflects the use of a continuous, constant rigidity, thin elastic-plate model by Drewry. To curtail these problems, the current topography of the Transantarctic Mountains is shown and graded into an artificial inland plateau with an altitude of $500 \mathrm{~m}$, simply for use as a reference level.

\section{SENSITIVITY EXPERIMENTS}

The eight inputs to the model are shown in Table 1. Figure 2 shows the evolution of the continental margin and the development of a mountain escarpment, formed only by the flexural response of the lithosphere to the denudational unloading across the margin. The final shape of the topography is determined by the initial topography and the interplay of the various components of denudation. The maximum elevation of the escarpment, here at $2400 \mathrm{~m}$ after $60 \mathrm{Ma}$, depends on the upward lithospheric flexure coupled with the accumulative denudation. The lithospheric flexure is shown in Figure 3 , indicating the downward flexure on the rifted side of the hinge and upward flexure to a maximum elevation of over $1700 \mathrm{~m}$ after $60 \mathrm{Ma}$ on the continental side of the hinge. Similarly, the accumulative denudation is shown

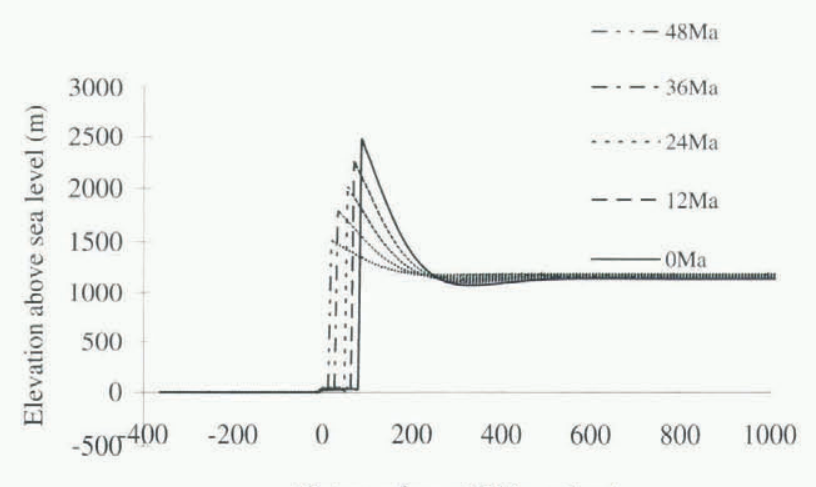

Distance from rift hinge $(\mathrm{km})$

Fig. 2. The evolution of the continental margin and the development of a mountain escarpment resulting from a combination of lithospheric flexure and accumulative denudation, from $60 \mathrm{Ma}$ to the present (0 Ma). 


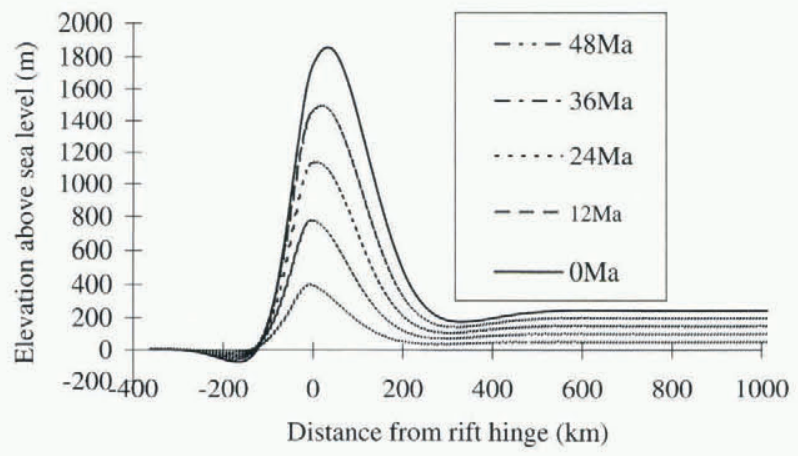

Fig. 3. The evolution of the lithospheric flexure caused by denudational unloading at the continental margin, from $60 \mathrm{Ma}$ to the present (OMa).

in Figure 4, indicating the removal of a wedge of material about $5 \mathrm{~km}$ thick at the rift hinge, reducing to a negligible thickness about $100 \mathrm{~km}$ inland. The shape of this wedge, which is constrained by fission-track data, can be manipulated by varying the rates of denudation across the continental margin. This puts tight constraints on the relative ratios of denudation across the margin but cannot by itself determine absolute rates. Finally, Figure 5 shows a comparison of the modelled topography with the present-day topographic profile of the Transantarctic Mountains in the Dry Valleys region. The present-day profile has higher relief though the wavelength of flexure is similar.

The shape of the modelled topographic profile depends on the value of the denudational components. Reducing the interior denudation to zero, as an extreme example, produces a higher topographic profile by about $100 \mathrm{~m}$ due to the coupled effect of reduced denudation and reduced flexural upwarping. Raising the interior denudation lowers the final topographic profile, because of increased denudation, despite increased flexural upwarping. If the interior denudation rate increases, the accumulative denudation profile becomes increasingly flattened until the interior rate exceeds the coastal zone rate, at which point the wedge profile narrows towards the coast. It follows that the conditions required to reproduce the fission-track data are strong differential

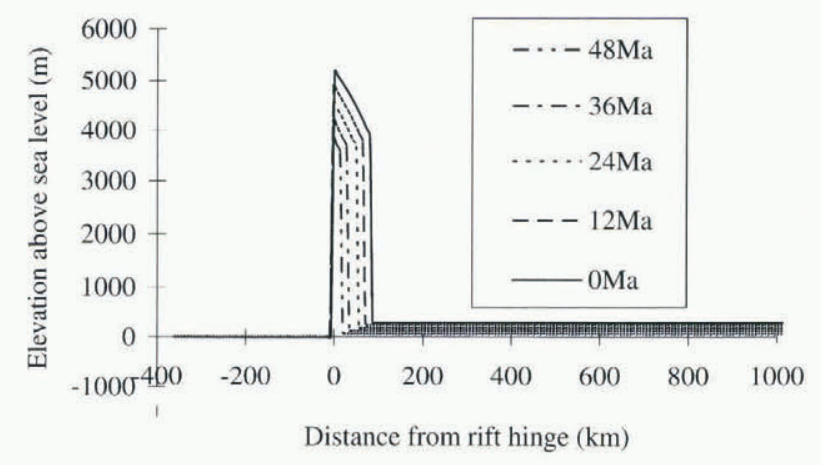

Fig. 4. The evolution of the accumulative denudation across the continental margin, which is constrained by fissiontrack data, from $60 \mathrm{Ma}$ to the present (O Ma).

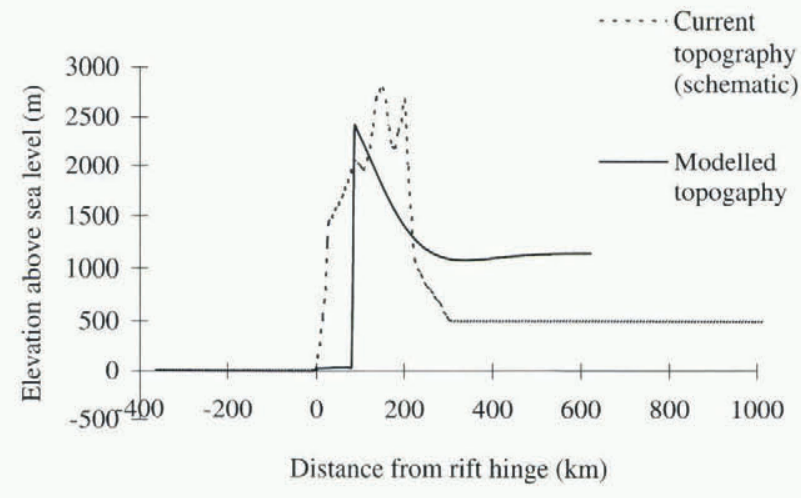

Fig. 5. A comparison between the modelled topography and a schematic profile of the present Transantarctic Mountains in the Dry Valleys area. Of note are the maximum elevation of the topography and the flexural wavelength rather than the quality of fit.

rates of denudation across the continental margin. The highest topographic profiles are obtained when interior denudation rates approach zero.

The coastal-zone denudation rate is sufficiently high to reduce the topography to sea level. If the coastal-zone denudation rate is lowered, coastal hills form and their shape is determined by the rate of escarpment retreat. This escarpment-retreat rate plays a crucial role on the altitude and wavelength of the topography. Reducing the retreat rate increases the wavelength of flexure and reduces the altitude of the topography, while increasing it achieves the opposite effect. However, an excessively high retreat rate leads to an overly narrow flexural wavelength and too much denudation at the rift hinge. The latter effect can be reduced by lowering the escarpment denudation and delicate interplay between these two parameters can lead to a topographic profile with an identical flexural wavelength to the present topography, and with a denudation profile which is within the constraints of the apatite fission-track data.

Varying the flexural rigidity of the unrifted lithosphere also varies the flexural wavelength and amplitude. Increasing it to an effective elastic thickness of $60 \mathrm{~km}$ reduces the flexural upwarp and the denudation, and the combined result is a reduction in the maximum topographic elevation. Reducing the flexural rigidity to $20 \mathrm{~km}$ leads to increased denudation, flexural upwarping and a rise in the maximum topographic elevation. Meanwhile, varying the rifted lithosphere by the same magnitude produces only minor variations in denudation, lithospheric flexure and topography.

The effect of varying each of six parameters, four denudational and two flexural, on maximum elevation is shown in Table 2. In general, the maximum elevation is linked to the flexural wavelength; smaller elevations equate to longer wavelengths.

Applying the same sensitivity tests with an initial topographic elevation of $500 \mathrm{~m}$ produces qualitatively similar results, though there is a larger mismatch between the final topographic profile and the current topography. Using an initial topography consisting of a coastal block at an elevation of $1200 \mathrm{~m}$ and the hinterland at $500 \mathrm{~m}$ 


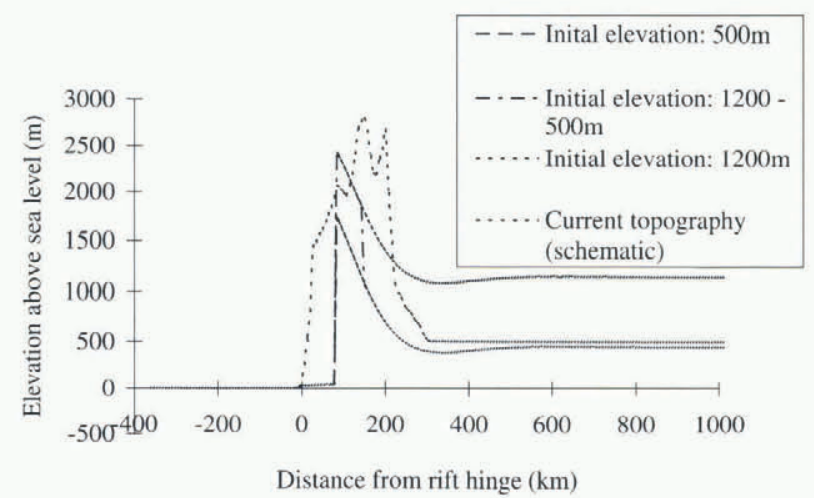

Fig. 6. A comparison between the modelled topography, assuming different initial topographic elevations, and a schematic profile of the present Transantarctic Mountains in the Dry Valleys area. An initial topographic elevation of $1200 \mathrm{~m}$ leads to a high hinterland; an initial elevation of $500 \mathrm{~m}$ leads to a low mountain escarpment; an initial elevation of $1200 \mathrm{~m}$ at the coast and $500 \mathrm{~m}$ in the hinterland produces a relatively good fit. Since the initial elevation is unknown, the implication is that we cannot delimit the role of differential denudation in forcing mountain uplift.

results in a much better fit between modelled and current topographic profiles (Figure 6).

\section{IMPLICATIONS FOR THE TRANSANTARCTIC MOUNTAINS}

The necessary conditions for producing a flexural wavelength which is comparable to the present Transantarctic Mountains are either a low effective elastic thickness in the unrifted continental lithosphere or a rapid escarpment retreat rate. The former is unlikely, while evidence indicates that the latter has occurred.

The necessary conditions required to satisfy the apatite fission-track data, that between 5 and $6 \mathrm{~km}$ of denudation occurred near the rift hinge reducing to $1 \mathrm{~km}$ at $75 \mathrm{~km}$, are a large escarpment-denudation rate and a high differential-denudation ratio between the interior and coastal zones.

To produce modelled topographic profiles of a comparable magnitude to the Transantarctic Mountains requires a high initial elevation and low absolute rates of denudation in the interior.

Sediment-loading offshore lowers the topographic profile on land, since the lithosphere is modelled as a continuous plate.

\section{DISGUSSION AND CONCLUSIONS}

This paper explores the response of a high-elevation passive margin to differential denudation. By utilizing available data pertaining to long-term glacial erosion, we show that glaciation can be an important process in reorganizing lithospheric loading over geological timescales. In the Transantarctic Mountains, three observations are pivotal. First, offshore seismic interpretations suggest that glacial processes have been operating in the Transantarctic Mountains since at least the Oligocene. Secondly, fission-track data indicate a substantial wedge of material has been eroded from the continental rift flank and, finally, high surface elevations imply surface uplift.

Table 2. The effect of varying the input parameters by $\pm 50 \%$ on the maximum elevation of the accumulative denudation, the lithospheric flexure and the topography. This is one of two possible measures, the second being the flexural wavelength; qualitatively, the results are similar

\begin{tabular}{|c|c|c|c|c|}
\hline & $\begin{array}{c}\% \text { change in } \\
\text { parameter } \\
\text { value }\end{array}$ & $\begin{array}{c}\text { Accumulative } \\
\text { denudation }\end{array}$ & $\begin{array}{l}\text { Lithospheric } \\
\text { flexure }\end{array}$ & $\begin{array}{l}\text { Maximum } \\
\text { topographic } \\
\text { elevation }\end{array}$ \\
\hline Escarpment denudation rate $\left(\mathrm{m} \mathrm{Ma}^{-1}\right)$ & $\begin{array}{r}+50 \% \\
-50 \%\end{array}$ & $\begin{array}{r}+49 \% \\
-49 \%\end{array}$ & $\begin{array}{r}+49 \% \\
-48 \%\end{array}$ & $\begin{array}{l}+28 \% \\
-28 \%\end{array}$ \\
\hline Interior denudation rate $\left(\mathrm{m} \mathrm{Ma}^{-1}\right)$ & $\begin{array}{r}+50 \% \\
-50 \%\end{array}$ & $\begin{array}{l}+1 \% \\
-1 \%\end{array}$ & $\begin{array}{r}+4 \% \\
-4 \%\end{array}$ & $\begin{array}{l}+2 \% \\
-2 \%\end{array}$ \\
\hline Coastal denudation rate $\left(\mathrm{m} \mathrm{Ma}^{-1}\right)$ & $\begin{array}{l}+50 \% \\
-50 \%\end{array}$ & $\begin{array}{l}0 \% \\
-4 \%\end{array}$ & $\begin{array}{r}0 \% \\
-4 \%\end{array}$ & $\begin{array}{r}0 \% \\
-2 \%\end{array}$ \\
\hline Escarpment retreat rate $\left(\mathrm{m} \mathrm{Ma}^{-1}\right)$ & $\begin{array}{l}+50 \% \\
-50 \%\end{array}$ & $\begin{array}{l}+9 \% \\
-13 \%\end{array}$ & $\begin{array}{r}+50 \% \\
-51 \%\end{array}$ & $\begin{array}{r}+19 \% \\
-28 \%\end{array}$ \\
\hline Elastic thickness $(\mathrm{km})$ : rifted lithosphere & $\begin{array}{r}+50 \% \\
-50 \%\end{array}$ & $\begin{array}{r}-3 \% \\
+10 \%\end{array}$ & $\begin{array}{r}-5 \% \\
+22 \%\end{array}$ & $\begin{array}{l}-1 \% \\
+4 \%\end{array}$ \\
\hline Elastic thickness $(\mathrm{km})$ : unrifted lithosphere & $\begin{array}{r}+50 \% \\
-50 \%\end{array}$ & $\begin{array}{r}-2 \% \\
+7 \%\end{array}$ & $\begin{array}{l}-16 \% \\
+37 \%\end{array}$ & $\begin{array}{r}-20 \% \\
+21 \%\end{array}$ \\
\hline
\end{tabular}


These observations are not inconsistent with the results of the differential-denudation model, provided specific conditions exist. These include a fast escarpment-retreat rate, though not necessarily a low flexural rigidity in the unrifted lithosphere, a high rate of denudation on the escarpment and a large differential between rates of denudation at the coast and in the interior. Lastly, and perhaps most importantly, the final topography is highly dependent on the elevation of the initial topography, which is poorly constrained.

The limitations of such an approach stem from the necessarily schematic model. While it is qualitatively reasonable to assume that much larger quantities of erosion take place on an escarpment front than in coastal regions or in the more continental and elevated hinterland, it is not clear that this can be translated into simple quantitative estimates of long-term denudation rates. In addition, the implications of sediment-filled grabens such as the Victoria Basin are not properly explored. Thus, we do not assert that glacial processes are crucial in driving rift-flank uplift but simply note that the available data are not inconsistent with such ideas.

At present, there are insufficient data to delimit the role of glacial erosional processes in forcing surface uplift in the Transantarctic Mountains and this paper is necessarily speculative. However, the flexural response of the lithosphere to such changes in loading, whether glacial or otherwise, appears to be one of the mechanisms capable of forcing tectonic uplift in the Transantarctic Mountains during the Cenozoic.

\section{ACKNOWLEDGEMENTS}

This research was supported by the U.K. Natural Environment Research Council, grant GR3/9128. The authors wish to thank M. Summerfield for helpful suggestions regarding the manuscript.

\section{REFERENGES}

Anderson, J. B. and L. R. Bartek. 1992. Cenozoic glacial history of the Ross Sea revealed by intermediate resolution seismic reflection data combined with drill site information. In Kennett, J.P. and D. A. Warnke, eds. The Antarctic paleoenviromment: a perspective on global change. Part 1. Washington, DC, American Geophysical Union, 56-65. (Antarctic Research Series 56.)
Beek, P. van der, S. Cloetingh and P. Andriessen. 1994. Mechanisms of extensional basin formation and vertical motions at rift flanks: constraints from tectonic modelling and fission track thermochronology, Earth Planet. Sci. Lett., 121, $417-433$.

Behrendt, J. C. and A. K. Cooper. 1991. Evidence of rapid Cenozoic uplift of the shoulder escarpment of the Cenozoic West Antarctic rift system and a speculation on possible climate forcing. Geology, 19 (4), 315-319.

Bell, M. and E. P. Laine. 1985. Erosion of the Laurentide region of North America by glacial and glaciofluvial processes. Quat. Res., $23(2), 154-174$

Bott, M. H.P. and T.A. Stern. 1992. Finite element analysis of the Transantarctic Mountain uplift and coeval subsidence in the Ross Embayment. Tectonophysics, 201 (3-4), 341-356.

Drewry, D.J., ed. 1983. Antarctica: glaciological and geophysical folio. Cambridge, Scott Polar Research Institute.

Fitzgerald, P.G. 1992. The Transantarctic Mountains of southern Victoria Land: the application of apatite fission track analysis to a rift shoulder uplift. Tectonics, 11 (3), 634662.

Gilchrist, A.R. and M.A. Summerfield. 1990. Differential denudation and flexural isostacy in formation of rifted margin upwarps. Nature, $346(6286), 739-742$.

Gilchrist, A. R. and M. A. Summerficld. 1994. Tectonic models of passive margin evolution and their implications for theories of longterm landscape development. In Kirkby, M.J., ed. Process models and theoretical geomorphology. New York, etc., John Wiley and Sons, 55 84.

Gleadow, A.J.W. and P.G. Fitzgerald. 1987. Uplift history and structure of the Transantarctic Mountains: new evidence from fission track dating of basement apatites in the Dry Valleys area, southern Victoria Land. Earth Planel. Sci. Lett., 82(1-2), 1-14.

Hall, A. M. and D. E. Sugden. 1987. Limited modifications of midlatitude landscapes by ice sheets: the case of northeast Scotland. Earth Surface Processes and Landforms, 12 (5), 531-542.

Nadai, A. 1963. Theory of flow and fracture of solids. First edition. New York, McGraw-Hill.

Stern, T.A. and U.S. ten Brink. 1989. Flexural uplift of the Transantarctic Mountains. 7. Geophys. Res., 94 B8), 10,315-10,330.

Sugden, D. E., D. R. Marchant and G. H. Denton. 1993. The case for a stable East Antarctic ice sheet: the background. Geogr. Ann., 75A(4), $151-154$.

Sugden, D.E., G. H. Denton and D. R. Marchant. 1995, Landscape evolution of the Dry Valleys, Transantarctic Mountains: tectonic implications. \%. Geophys. Res., 100 B7), 99499967.

Ten Brink, U.S., S. Bannister, B. C. Beaudoin and T. A. Stern. 1993. Geophysical investigations of the tectonic boundary between East and West Antarctica. Science, 261 (5117), 45-50.

Ten Brink, U. and T. Stern. 1992. Rift flank uplifts and hinterland basins: comparison of the Transantarctic Mountains with the Great Escarpment of southern Africa. 7. Geophys. Res., 97 B1), 569585.

Tessensohn, F. and G. Worner. 1991. The Ross Sea rift system: structure, evolution and analogues. In Thomson, M.R.A., J.A. Crane and J. W. Thomson, eds. Geological evolution of Antartica. New York, etc., Cambridge University Press, 273277.

Wellman, P. and R.J. Tingey. 1981. Glaciation, erosion and uplift over part of East Antarctica. Nature, 291 (5811), 142-144.

Wilson, G. S. 1995. The Neogene East Antarctic ice sheet: a dynamic or stable feature? Quat. Sci. Rev., 14, 101-123. 